\title{
Evaluation of Microstructure and Mechanical Properties of Seamless Steel Pipes API 5L Type Obtained by Different Processes of Heat Treatments
}

\author{
Leonardo Barbosa Godefroid ${ }^{*}$, Betânia Mendes Sena ${ }^{a}$, Vicente Braz da Trindade Filho ${ }^{a}$ \\ ${ }^{a}$ REDEMAT, Universidade Federal de Ouro Preto, Ouro Preto, MG, Brazil
}

Received: July 18, 2016; Revised: December 12, 2016; Accepted: February 02, 2017

\begin{abstract}
This research presents the influence of manufacturing processes and heat treatments on the resulting microstructures and mechanical properties of an API 5L PSL2 seamless steel pipe. Three different conditions are considered - as rolled, normalized and quenched and tempered - to obtain the grades X42R, X42N and X70Q, respectively. Scanning electron microscopy techniques was used to characterize the resultant microstructures. Tensile, hardness, impact, fracture toughness ( $\mathrm{J}$ integral) and fatigue crack growth tests $(\mathrm{da} / \mathrm{dN} \times \Delta \mathrm{K})$ were used to study the materials mechanical behavior. The results show the possibility of achieving API grades for a seamless pipeline steel, through suitable heat treatments. The microstructural modifications and mechanical properties changes observed showed a remarkable structure-properties relationship of the steel, and attempt to a proper selection as required by the structural design. The quenching and tempering process increased tensile mechanical properties and fracture toughness, but combined to a significant decrease in fatigue crack growth resistance.
\end{abstract}

Keywords: Seamless steel pipes; API 5L line pipe; Fracture toughness; Fatigue crack growth

\section{Introduction}

High strength low alloys steels (HSLA) have been used for the production of pipes for more than 30 years. However, the alloy design of pipeline grades is being continuously modified and the process technology optimized because of increasing demand of high strength-toughness combination requirement of pipeline steels ${ }^{1-11}$. This demand is related to the increase of oil and gas world production and the consumption of their products. To achieve this demand, it is necessary that the pipes have large diameters and work under high internal pressures in order to increase the transportation efficiency, and avoid the use of very high wall thicknesses in order to reduce its weight and to decrease the project cost. The microalloyed steels are obtained by thermomechanical processing (in case of welded pipes) or heat treatment, e.g. quenching and tempering heat treatment (in case of seamless pipes), and have a characteristically microstructure consisting of well-selected phases and refined grain sizes.

The American Petroleum Institute (API) provides standards for pipe that are suitable for use in conveying gas, water, and oil in both the oil and natural gas industries. The API $5 \mathrm{~L}^{12}$ specification describes the requirements of chemical composition, tensile test characteristics and impact toughness behavior. The property requirements of steel vary depending on the particular application and operating conditions. The basic requirements, however, are high mechanical strength together with superior toughness at low temperature and excellent weldability. It is also important that steels should exhibit superior corrosion resistance.
Cracks can nucleate and propagate in pipelines during its operation, while the structure can be subjected to operational static overloads or cyclic loads, and a catastrophic failure can occur. In this context, the knowledge about the resistance to fracture of steels is very important, to provide information for pipeline design and materials selection during construction and predict the operational life of pipeline. To evaluate fracture properties of pipeline steels, various laboratoryscale testing methods have been studied since 1980s. Among them, Charpy V-notch impact test (CVN) and drop-weight tear test (DWTT) are most widely used to characterize the resistance to static loads, while S-N curves and $\varepsilon-\mathrm{N}$ curves represent the fatigue behavior of the steel. However, these methods are not based on fracture mechanics concepts to evaluate fracture toughness and fatigue resistance, and their data have large deviations because they largely depend on the specimen size and geometry. Little information is available on fracture toughness ${ }^{13-19}$ and fatigue crack growth resistance ${ }^{20-22}$, mainly on near-threshold fatigue crack growth behavior. It is also important to note that the publications are mainly concentrated on welded microalloyed steel pipes, obtained from thermomechanical operations (controlled rolling), with a characteristically complex microstructure. Regardless of the manufacturing process, the technical literature assigns an improvement of mechanical properties to the strict control of chemical composition (especially inclusion content and shape control, presence of microalloyed elements), lower volume fraction of M-A constituent, smaller effective ferritic grain size, presence of acicular ferrite, refinement of the martensitic structure ${ }^{14,18,23-31}$. 
Conventional heat treatments applied to seamless steel pipes result in special microstructures that allow greater mechanical resistance and fracture toughness than thermomechanical processing applied to welded steel pipes, showing the advantage of manufacturing seamless steel pipes when compared to welded steel pipes. Consequently, it can observe that seamless steel pipes do not require high grades as welded pipes because intermediate grades for the seamless pipes have similar mechanical properties to the high grades for the welded pipes. There is a huge advantage in the manufacturing process of seamless steel pipes, because from a relatively simple steel, as the steel in this research, and with the assistance of conventional heat treatment processes, it is possible to achieve intermediate grades, unlike welded pipes that require more elaborate and rigorous chemical composition in addition to a specific thermomechanical processing with many processing parameters such as reheating temperature, percentage reduction, deformation temperature, cooling rate, and coiling temperature. Unfortunately, much of what is studied about seamless steels is not published due to industrial restrictions and information security, but engineers and researchers in the Vallourec Group (one of the most important world producer of seamless steel pipes) has access to this information and mention the advantages of this route for the production of pipes in their papers ${ }^{32-34}$.

Therefore, the present research was carried out to evaluate the behavior of an API 5L PSL2 seamless pipeline steel manufactured by one of the Vallourec steel plants in Brazil. Three different processing routes were adopted - hot rolling, normalizing heat treatment and quenching and tempering heat treatment - to achieve three different API grades: X42R, X42N and X70Q, respectively. An objective of this research was to show the possibility of achieving API $5 \mathrm{~L}$ grades from a seamless steel pipe, using a relatively simple chemical composition and conventional heat treatments (a relatively inexpensive steel). Another objective of this study was to verify the influence of the resultant microstructures on mechanical properties of the seamless steel pipe, mainly its fracture toughness and its fatigue crack growth resistance.

\section{Materials and Experimental Procedures}

The steel studied was manufactured by the company Vallourec \& Sumitomo Tubos do Brasil (VSB) and was provided as seamless steel pipe with nominal outside diameter measuring $219.10 \mathrm{~mm}$ and wall thickness measuring $8 \mathrm{~mm}$. Table 1 presents the range of nominal chemical composition of this microalloyed steel, according to the API 5L PSL2 Standard ${ }^{12}$. The ranges are adapted by the company VSB, as an international routine, to control its production and meet customers' specifications. The starting point for this research was an API X42R grade steel, in as hot-rolled condition. After that, heat treatments of normalizing and quenching/ tempering were performed, in order to try to achieve the X42N and X70Q grades, respectively.

The temperature of $910^{\circ} \mathrm{C}$ was adopted for the austenitizing temperature, due to the fact that the $\mathrm{A}_{\mathrm{C} 3}$ temperature for this steel is $835^{\circ} \mathrm{C}$, according to the manufacturer. For the normalizing heat treatment, specimens were austenitized in an electric resistance furnace, and air cooled to room temperature, aimed to obtain the API X42N grade. For the quenching/tempering heat treatment, the austenitization was performed in the same way as in the previous case. The quenching process was carried out in water at $30^{\circ} \mathrm{C}$, and the temperature of $650^{\circ} \mathrm{C}$ for the tempering process was chosen to obtain the API X70Q grade.

Chemical analysis of the pipe was performed by means of an optical emission spectrometer. A specimen of $40 \mathrm{~mm} x$ $40 \mathrm{~mm}$ was removed from the pipe and analyzed, according to the API Standard ${ }^{12}$.

Specimens taken from the transversal direction were mechanically polished and etched by a $2 \%$ Nital reagent. The microstructures were observed by a scanning electron microscope (SEM). Ferritic grain size and degree of banding were obtained through the ASTM E112 ${ }^{35}$ and ASTM E $1268^{36}$, respectively.

All the mechanical tests were conducted at room temperature. Tensile, hardness and Charpy impact tests were performed according to the API 5L Standard ${ }^{12}$. Tensile tests, fracture toughness tests ( $J$ integral, R-curve) and fatigue crack growth tests $(d a / d N x \Delta K)$ were conducted on a 10ton servo-hydraulic testing machine interfaced to a computer for machine control and data acquisition. Tensile specimens were taken from transversal direction, and made with rectangular section (length of reduced section $=59 \mathrm{~mm}$; width $=38 \mathrm{~mm}$ ). $\mathrm{C}(\mathrm{T})$ test specimens $(7.2 \mathrm{~mm}$ thick, $28.8 \mathrm{~mm}$ wide) in T-L orientation were used for all the fracture toughness and fatigue tests. The SEM was used to characterize the fracture surfaces of all the mechanically tested specimens.

Fracture toughness tests (J-integral, R-curve) were carried out in accordance with the ASTM E1820 Standard ${ }^{37}$, under displacement control in test specimens with an a/W (crack size to width) equal to 0.50 , displacement intervals of 0.2 $\mathrm{mm}, 10 \%$ of unloading at each step, two stages of unloading at each step, $5 \mathrm{~s}$ of time interval for crack growth in each step. Experimental $\mathrm{J}$ integral estimates were made by separating the $\mathrm{J}$ value into elastic and plastic components. From the tests, the $J-\Delta$ a curves were traced for the three steel grades and the value of $\mathrm{J}_{\mathrm{Q}}$ (the toughness of the material near the onset of crack extension) was calculated. In this work $J_{Q} \neq$ $J_{I C}$, once the thickness used for the test specimens did not satisfy the standard requirement. In other words, the results are a function of the thickness considered (constant in this case) to the test specimens and $\mathrm{J}_{\mathrm{Q}}$ is a size-dependent value of fracture toughness. Three test specimens were used for each steel grade. 
Table 1. Nominal chemical composition of API steel $(\mathrm{wt} \%)^{12}$.

\begin{tabular}{llllllll}
\hline ELEMENT & $\mathrm{C}$ & $\mathrm{Mn}$ & $\mathrm{Si}$ & $\mathrm{P}$ & $\mathrm{S}$ & $\mathrm{Al}$ & $\mathrm{Cu}$ \\
\hline RANGE & 0.18 & 1.00 & 0.20 & 0.000 & 0.000 & 0.020 & 0.00 \\
& 0.20 & 1.10 & 0.30 & 0.020 & 0.010 & 0.040 & 0.20 \\
ELEMENT & $\mathrm{Cr}$ & $\mathrm{Ni}$ & $\mathrm{Mo}$ & $\mathrm{Ti}$ & $\mathrm{V}$ & $\mathrm{Nb}$ & $\mathrm{N}$ \\
RANGE & 0.00 & 0.00 & 0.000 & 0.000 & 0.02 & 0.000 & 0.0000 \\
& 0.20 & 0.20 & 0.070 & 0.010 & 0.03 & 0.010 & 0.0120 \\
\hline
\end{tabular}

Fatigue crack growth tests were performed under a sinusoidal waveform at a frequency of $30 \mathrm{~Hz}$ with a load ratio of 0.1 , in accordance with the recommendations of ASTM E647 Standard ${ }^{38}$. Crack size curves as a function of the number of cycles have been obtained, and transformed to crack growth rate curves $(d a / d N)$ as a function of cyclic stress intensity factor $(\Delta \mathrm{K})$. Two test pieces were used to obtain these curves. The fatigue threshold value $\Delta K_{T H}$ was defined as the stress intensity factor range at which the fatigue crack growth rate reached $1 \times 10^{-7} \mathrm{~mm} /$ cycle. This value was estimated by a $\mathrm{K}$-decreasing procedure. Closure measurements $\left(K_{C L} / K_{\max }\right)$ were calculated during the fatigue tests, through the compliance technique, where a change of linearity was formed in the applied load versus COD curve.

\section{Results and Discussion}

Chemical analysis of the hot-rolled steel studied confirms that the material meets the required specifications by the API $5 \mathrm{~L}^{12}$. It is a steel with a relatively simple chemical composition, with a carbon equivalent $\mathrm{CE}_{\text {IIW }}<0.38$ (maximum $=0.43$ ). For the PSL2 level, the CE value is one of the main requirements in relation to the weldability of the material. In the present study, the carbon content $(\mathrm{C}<0.2 \%)$ and $\mathrm{CE}$ indicate a region of good weldability in "Granville diagram" (chart relating the carbon content with carbon equivalent, indicating regions of weldability: good, with special care, and low) for HSLA and API steels ${ }^{39,40}$. Another important point to be considered is the presence of vanadium $(0.02 \% \mathrm{~V})$ in the chemical composition of the steel, an element added mainly for precipitation strengthening and microstructure refinement. The presence of this unique microalloyed element allows the reduction of the carbon content, ensuring improved weldability and fracture toughness ${ }^{28,29}$.

Microstructural analysis showed that hot-rolled and normalized steels had a microstructure consisting of polygonal ferrite and pearlite with a slight banding - ASTM ${ }^{36}$ degree of banding between 0.13 and 0.28 , a common occurrence in hot-rolled, low alloy steels ${ }^{41,42}$. Figure 1(a,b) shows these microstructures. Acicular ferrite, bainite or M-A constituent have not been verified. The normalized steel showed an ASTM ferritic grain size 9 while the hot-rolled steel showed an ASTM grain size $6\left(\mathrm{ASTM}^{35}\right)$, a reduction of approximately $30 \%$ in grain size. The quenched/tempered steel showed a matrix consisting of tempered martensite, bainite and a fine

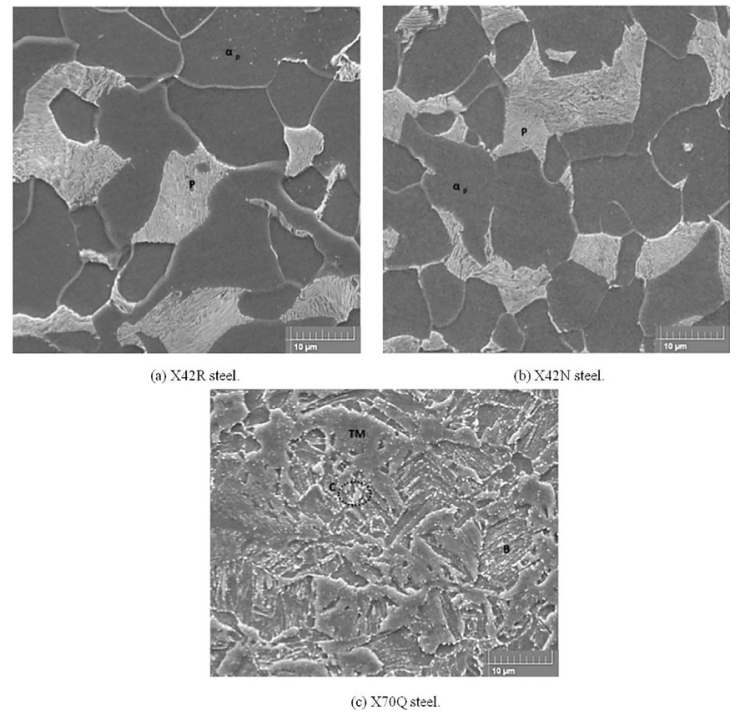

Figure 1. SEM micrographs, longitudinal section. Nital 2\% etching. $\alpha \mathrm{p}=$ polygonal ferrite; $\mathrm{P}=$ pearlite $\mathrm{TM}=$ tempered martensite; $\mathrm{B}$ $=$ bainite C $=$ cementite particles.

distribution of precipitated carbides (cementite particles), as shown in Figure 1(c). As the steel studied has vanadium in its chemical composition, it should expect also the precipitation of vanadium carbides in all microstructures ${ }^{28,29}$.

Table 2 shows basic tensile mechanical properties obtained in this study for the three API steels. In this Table, the values specified by the API standard ${ }^{12}$ for the three grades considered in this research are also presented. The first important conclusion from the analysis of Table 2 is that the hot rolled steel has met the requirements for the X42R grade of the API standard ${ }^{12}$. The two heat treatments applied to the $\mathrm{X} 42 \mathrm{R}$ grade have changed the microstructure of this steel, to obtain the $\mathrm{X} 42 \mathrm{~N}$ and $\mathrm{X} 70 \mathrm{Q}$ grades, respectively. To better analyze the structure-properties relationship, it is interesting to separate the materials under study in two families of HSLAAPI type steels: the ferrite-pearlite microstructure family (X42R and $\mathrm{X} 42 \mathrm{~N}$ ) and the tempered martensite microstructure family (X70Q). The ferrite-pearlite steels family showed similar tensile mechanical properties, despite the change in its ferrite grain size, with resistance variation less than $5 \%$ and ductility variation less than $10 \%$. The quenching and tempering heat treatment promoted a significant increase in the yield stress (between $48 \%$ and $55 \%$, compared with X42R and X42N steels, respectively) and in the ultimate stress of the steel (between $18 \%$ and $22 \%$, compared with the other steels, respectively), with a small loss of its ductility (between $11 \%$ and $18 \%$, compared with the other steels, respectively). This behavior is consistent with the literature ${ }^{13-19,23-34,43-53}$, and can be explained by the presence of hardening constituents on its microstructure (tempered martensite, bainite and precipitates). Ductile behavior can still be observed in the three steels by their mechanism of fracture, regardless of the difference in mechanical properties: tensile test specimens 
Table 2. Tensile mechanical properties of the studied steels.

\begin{tabular}{|c|c|c|c|c|c|c|c|c|}
\hline $\begin{array}{l}\text { STEEL } \\
\text { GRADE }\end{array}$ & YS (MPa) & $\begin{array}{c}\text { API } \\
\text { Standard }\end{array}$ & UTS (MPa) & $\begin{array}{c}\text { API } \\
\text { Standard }\end{array}$ & $\begin{array}{c}\text { Ratio YS/ } \\
\text { UTS }\end{array}$ & $\begin{array}{c}\text { API } \\
\text { Standard }\end{array}$ & ELO (\%) & $\begin{array}{c}\text { API } \\
\text { Standard }\end{array}$ \\
\hline $\mathrm{X} 42 \mathrm{R}$ & $370 \pm 5$ & $290-495$ & $536 \pm 3$ & $415-760$ & 0.69 & 0.93 (max.) & $35 \pm 1$ & 27 (min.) \\
\hline $\mathrm{X} 42 \mathrm{~N}$ & $352 \pm 5$ & $290-495$ & $518 \pm 3$ & $415-760$ & 0.68 & 0.93 (max.) & $38 \pm 1$ & 27 (min.) \\
\hline X70Q & $546 \pm 8$ & $485-635$ & $631 \pm 9$ & $570-760$ & 0.86 & 0.93 (max.) & $31 \pm 1$ & 21 (min.) \\
\hline
\end{tabular}

$\mathrm{YS}=$ yield stress; UTS $=$ ultimate stress; ELO $=$ strain at fracture.

showed the operation of the mechanism of nucleation, growth and coalescence of microvoids. All these results reaffirm the possibility to control mechanical properties through the choice of a suitable microstructure in a seamless pipe. From the perspective of increased mechanical strength, the $\mathrm{X} 70 \mathrm{Q}$ grade steel obtained with the quenched and tempered microstructure stands out in this context, because it has been obtained from a relatively simple chemical composition and with a conventional heat treatment.

Table 3 shows the hardness results of the different steel grades. The results are consistent with the purpose of each heat treatment: in the case of normalizing (X42N), it promotes a stress relief on the material, making it more homogeneous and reducing its hardness (reduction of 7\% in comparison with the X42R steel); the quenching and tempering $(\mathrm{X} 70 \mathrm{Q})$ aims to increase the hardness (increase of $33 \%$ in comparison with the $\mathrm{X} 42 \mathrm{R}$ steel) and tensile strength by martensitic transformation and precipitations. It is important to note that the hardness value of the $\mathrm{X} 70 \mathrm{Q}$ steel refers to a tempered martensite microstructure. Comparing Tables 2 and 3, it is interesting to observe the obedience of the traditional direct relationship between tensile mechanical strength and hardness for the steels.

Table 3. Vickers Hardness (HV10) of the studied steels.

\begin{tabular}{lc}
\hline STEEL GRADE & HV \\
\hline X42R & $157 \pm 2$ \\
X42N & $146 \pm 1$ \\
X70Q & $208 \pm 6$ \\
\hline
\end{tabular}

Table 4 shows the Charpy impact results obtained in the three steels at temperatures of $0^{\circ} \mathrm{C}$ and $21^{\circ} \mathrm{C}$. The quenched and tempered steel $(\mathrm{X} 70 \mathrm{Q})$ presented a better performance, i.e., more than double the energy absorbed at $0^{\circ} \mathrm{C}$ and more than $50 \%$ at $21^{\circ} \mathrm{C}$ compared to the hot rolled steel (X42R). Comparing Tables 2 and 4 , it can be concluded that the steel with tempered martensite microstructure ensured a mechanical strength and ductility able to give a better impact toughness 13-19, 23-34, 43-53. This behavior has been confirmed by fracture analysis of the test specimens, since the X70Q steel kept the ductile fracture mechanism at both temperatures.

Table 5 compares tensile and Charpy impact results of this work with some results of the technical literature. It was considered the API X70 grade as a basis for comparison, i.e.,
Table 4. Charpy impact properties of the studied steel.

\begin{tabular}{lcccc}
\hline \multirow{2}{*}{ STEEL } & \multicolumn{2}{c}{ AE $(\mathrm{J})$} & \multicolumn{2}{c}{$\mathrm{DF}(\%)$} \\
GRADE & $0^{\circ} \mathrm{C}$ & $21^{\circ} \mathrm{C}$ & $0^{\circ} \mathrm{C}$ & $21^{\circ} \mathrm{C}$ \\
\hline $\mathrm{X} 42 \mathrm{R}$ & $33 \pm 3$ & $50 \pm 5$ & $47 \pm 7$ & $68 \pm 11$ \\
$\mathrm{X} 42 \mathrm{~N}$ & $69 \pm 2$ & $76 \pm 03$ & $100 \pm 0$ & $100 \pm 0$ \\
$\mathrm{X} 70 \mathrm{Q}$ & $80 \pm 2$ & $82 \pm 5$ & $100 \pm 0$ & $100 \pm 0$ \\
\hline
\end{tabular}

AE: absorbed energy; DF: \% of ductile fracture.

results of API X70Q seamless steel of this work compared with results of the same API X70 grade from other researchers that obtained the steel by thermomechanical processing. This Table also shows the microalloying elements used in each steel, and the corresponding microstructures. Two important conclusions must be highlighted. Considering the route of manufacture of steel by thermomechanical processing, typical for welded steels, to provide comparable values of mechanical properties with seamless steel obtained by simple heat treatments, it is necessary the use of several microalloying elements. Still considering the typical route for welded steels, several thermomechanical parameters should be adjusted, for creating more complex microstructures than in the case of seamless steel. In order to ensure good mechanical properties, it is shown the complicated manufacturing process (and, of course, the greatest cost involved) of welded steels in relation to seamless steel, as emphasized in the introduction to this work.

The fracture toughness of the studied steels can be seen in Figure 2, through the calculation of the $J$ integral and the corresponding resistance curves (toughness $J$ versus crack increment $\Delta a$ ). All construction lines required by ASTM E1820 are shown in this figure, with calculations made for the quenched and tempered steel. The $J_{Q}$ value represents the fracture toughness for starting stable crack growth. It can be observed that the quenched and tempered steel (X70Q) presented the best performance, i.e., a 50\% increase in fracture toughness compared to the normalizing steel $(\mathrm{X} 42 \mathrm{~N})$ and an increase of almost $80 \%$ in relation to the hot rolled steel (X42R). This fact is again due to its microstructure ${ }^{13-19,23-34,43-53}$, consisting of tempered martensite, bainite and precipitated carbides.

Just as in the case of tensile and impact tests, the fracture mechanism in steels tested to determine their fracture toughness was the same for the three microstructures, i.e., nucleation, growth and coalescence of microvoids, typical 
Table 5. Tensile and impact properties - comparison among this research (seamless steel) and other works (thermomechanical processing steels). Data from API X70 grade steel.

\begin{tabular}{lcccccc}
\hline Reference & YS $(\mathrm{MPa})$ & UTS $(\mathrm{MPa})$ & ELO $(\%)$ & $\mathrm{AE}, 0^{\circ} \mathrm{C}(\mathrm{J})$ & Microalloyed elements & Microstructure \\
\hline This work & 546 & 631 & 31 & 80 & $\mathrm{~V}$ & $\mathrm{TM}+\mathrm{B}+\mathrm{C}$ \\
$(14)$ & 517 & 663 & 28 & 461 & $\mathrm{Nb}+\mathrm{Ti}+\mathrm{V}$ & $\mathrm{PF}+\mathrm{AF}+\mathrm{MA}+\mathrm{RA}$ \\
$(25)$ & 471 & 580 & 33 & 194 & $\mathrm{Ti}+\mathrm{Nb}$ & $\mathrm{PF}+\mathrm{AF}+\mathrm{B}+\mathrm{MA}+\mathrm{C}$ \\
$(26)$ & 735 & 791 & 16 & 27 & $\mathrm{Ti}+\mathrm{Nb}$ & $\mathrm{PF}+\mathrm{B}+\mathrm{MA}+\mathrm{C}$ \\
$(51)$ & 530 & 600 & 26 & 127 & $\mathrm{Nb}+\mathrm{Ti}+\mathrm{V}$ & $\mathrm{PF}+\mathrm{P}$ \\
$(19)$ & 471 & 580 & 33 & 268 & $\mathrm{Nb}+\mathrm{Ti}+\mathrm{Al}$ & $\mathrm{AF}+\mathrm{PF}+\mathrm{B}+\mathrm{MA}+\mathrm{C}$ \\
$(31)$ & 530 & 840 & 26 & 220 & $\mathrm{Nb}+\mathrm{Ti}+\mathrm{V}$ & $\mathrm{F}+\mathrm{M}($ dual-phase $)$ \\
$(22)$ & 586 & 640 & 38 & 184 & $\mathrm{Nb}+\mathrm{Ti}+\mathrm{V}$ & $\mathrm{PF}+\mathrm{P}+\mathrm{B}+\mathrm{C}$ \\
\hline
\end{tabular}

$\mathrm{YS}=$ yield stress; UTS $=$ ultimate stress; $\mathrm{ELO}=$ strain at fracture; $\mathrm{AE}=$ absorbed energy. PF: polygonal ferrite; AF: acicular ferrite; $\mathrm{F}$ : ferrite; M: martensite; P: pearlite; B: bainite; MA : martensite-austenite constituent; RA: retained austenite; C: carbides.

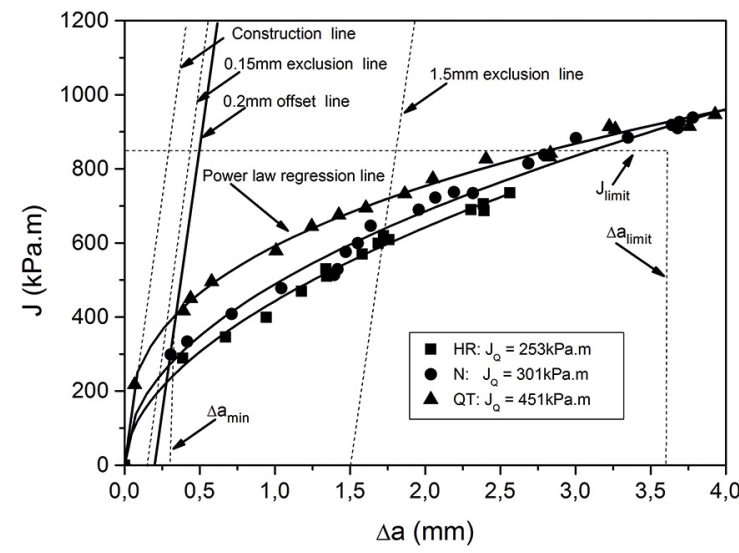

Figure 2: J- $\Delta a$ resistance curves for the three steels. HR $=$ hotrolled; $\mathrm{N}=$ normalized; $\mathrm{QT}=$ quenched and tempered. The value of $\mathrm{J}_{\mathrm{Q}}$ is showed for the steels.

ductile fracture. Figure 3 illustrates this mechanism for all steels. The fracture surface of the specimens analyzed corresponds approximately to a crack size related to the value of $J_{Q}$. It is interesting to note the increased amount of dimples present in fractures of ferrite-pearlite families than the tempered martensite family, due to its greater ductility.

Fracture toughness is confronted with the tensile mechanical resistance in Figure 4. To better analyze this relationship, it is interesting to separate again the steels in two families, of ferrite-pearlite microstructure (X42R and X42N) and of tempered martensite microstructure (X70Q). As also noted in the impact tests, the X70Q grade steel achieved a better combination of mechanical properties than the X42R and $\mathrm{X} 42 \mathrm{~N}$ grade steels.

With respect to the fatigue crack growth resistance, the behavior of the three steels is different in the near-threshold regime (region $\mathrm{I}, \Delta K_{T H}$ ) and similar in the linear regime (region II, the well-known Paris regime) of the traditional sigmoidal curve $d a / d N x \Delta K$. Figure 5 presents the fatigue crack growth rates of the steels as a function of $\Delta K$. In the near-threshold regime, the fatigue crack growth rate of the

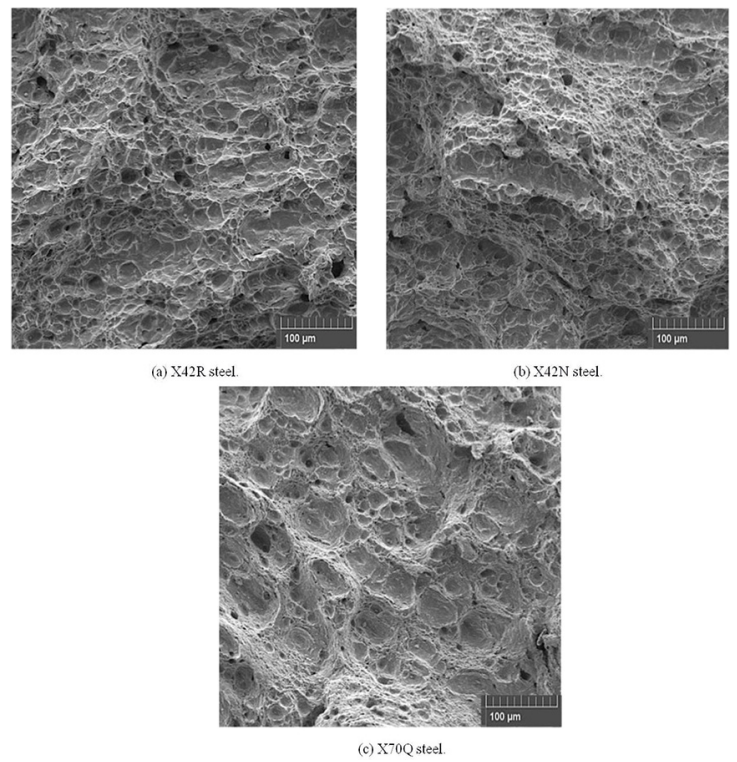

Figure 3. SEM fractographies, $\mathrm{J}$ integral test specimens, $\Delta a$ corresponding to $J_{Q}$.

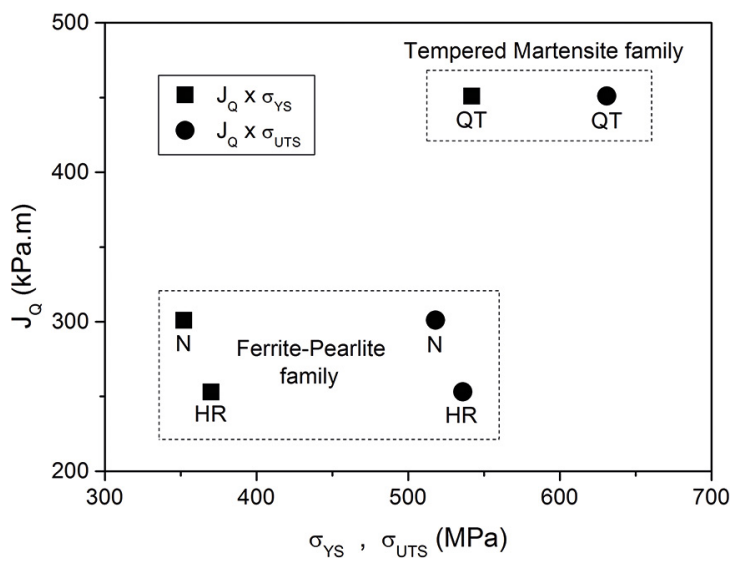

Figure 4. Fracture toughness and tensile mechanical resistance relationship. $\mathrm{HR}=$ hot-rolled; $\mathrm{N}=$ normalized; $\mathrm{QT}=$ quenched and tempered. 


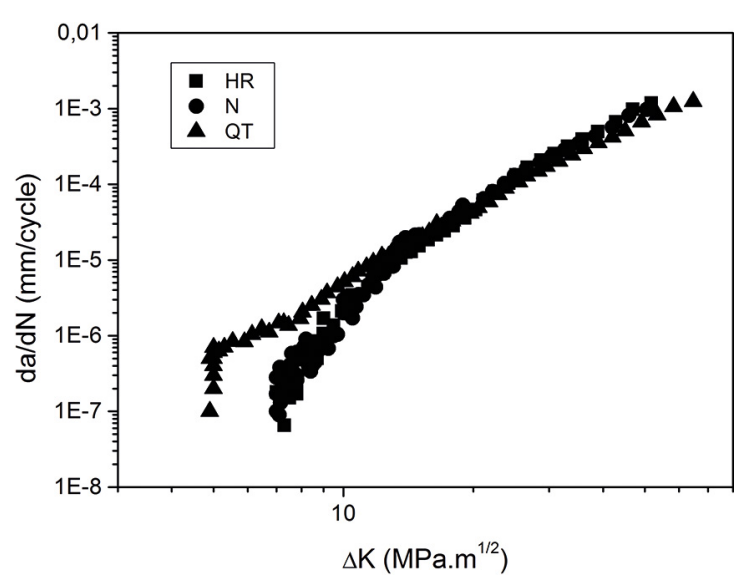

Figure 5. Fatigue crack growth results. $H R=$ hot-rolled; $N=$ normalized; QT = quenched and tempered.

X70Q grade steel was lower than that of the steels with ferrite-pearlite microstructure (a reduction of 31\%). At higher crack growth rate the sigmoidal curves tended to converge. These behaviors can be explained by the crack closure phenomenon ${ }^{20-22,54,55}$. Figure 6 presents the crack closure levels of the three steels as a function of $\Delta \mathrm{K}_{\mathrm{TH}}$. It is possible to see that the $K_{C L} / K_{\max }$ ratio was slightly different for the $\mathrm{X} 42 \mathrm{R}$ and $\mathrm{X} 42 \mathrm{~N}$ grade steels, but highly different for the $\mathrm{X} 70 \mathrm{Q}$ grade steel (a reduction of $76 \%$ ). Two mechanisms are considered to explain crack closure in this region: roughness and/or oxide. The fatigue specimens showed, for both steels studied, a transgranular fracture surface, without corrosion deposits. A rough surface was observed, suggesting the operation of roughness-induced crack closure.

Rough fracture surfaces with shear regions ("faceted" surfaces, characteristic of crystallographic crack growth) of $\Delta K$ near to crack growth threshold $\left(\right.$ da $/ d N \cong 10^{-7} \mathrm{~mm} /$ cycle $)$, and more flat fracture surfaces with fatigue striations in the linear region of crack growth $\left(d a / d N \cong 10^{-4} \mathrm{~mm} / \mathrm{cycle}\right)$ are illustrated in Figure 7(a,b) for all steels. These different crack growth mechanisms are typical of fatigue cracking in the two regions ${ }^{22,54,55}$.

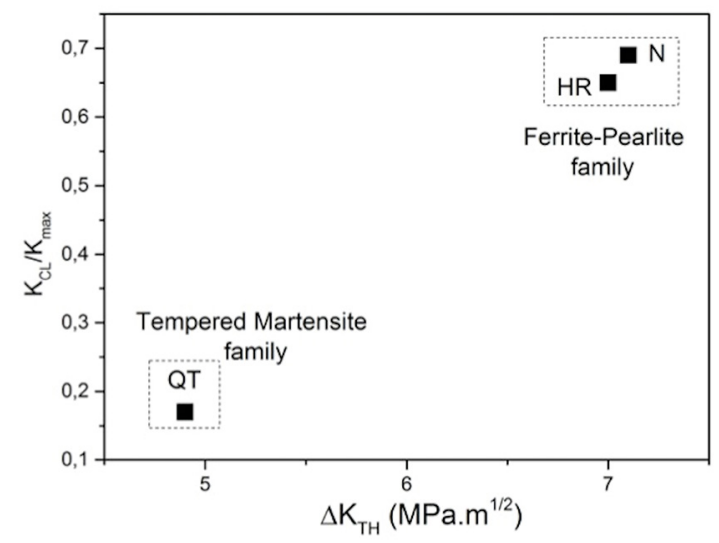

Figure 6. Closure measurements in function of the threshold. $\mathrm{HR}=$ hot-rolled; $\mathrm{N}=$ normalized; $\mathrm{QT}=$ quenched and tempered.

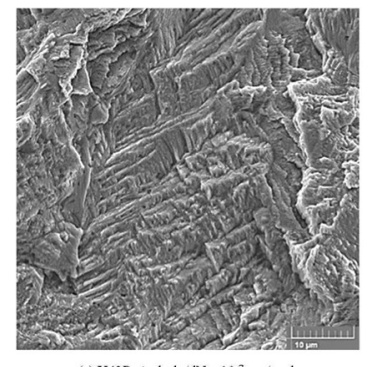

(a) $\mathrm{X} 42 \mathrm{R}$ steel, $\mathrm{d} a / \mathrm{dN} \sim 10^{-7} \mathrm{~mm} / \mathrm{cycle}$.

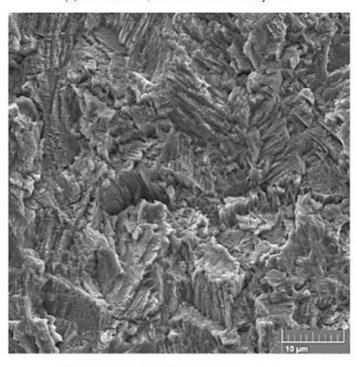

(c) $\mathrm{X} 42 \mathrm{~N}$ steel, da $/ \mathrm{dN} \sim 10^{-7} \mathrm{~mm} /$ cycle.

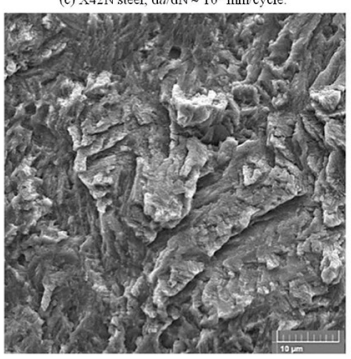

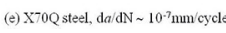

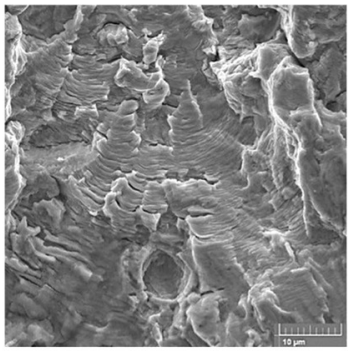

(b) $\mathrm{X} 42 \mathrm{R}$ steel, $\mathrm{d} / / \mathrm{IN} \sim 10^{-4} \mathrm{~mm} / \mathrm{cycle}$

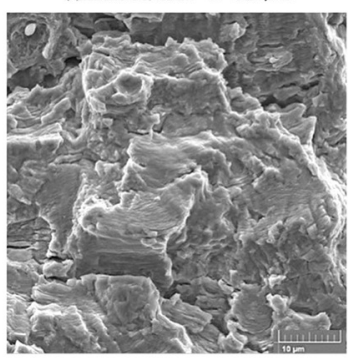

(d) $\mathrm{X} 42 \mathrm{~N}$ steel, $\mathrm{d} c / \mathrm{dN} \sim 10^{-4} \mathrm{~mm}$ cycle

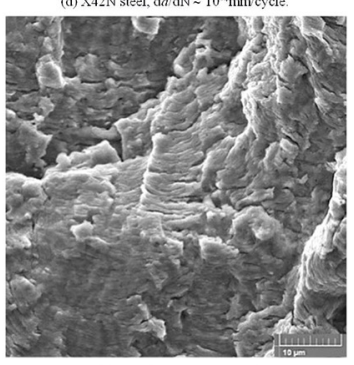

(f) $\mathrm{X} 70 \mathrm{Q}$ steel, $\mathrm{d} / \mathrm{dN} \sim 10^{-4} \mathrm{~mm} / \mathrm{cycle}$
Figure 7. SEM fractographies, fatigue specimens at two crack growth rates.

The relationship between the threshold $\Delta K_{T H}$ and tensile mechanical resistance can be seen in Figure 8. It is possible to see the loss of fatigue crack growth resistance with increasing tensile mechanical strength. High tensile mechanical strength constrains the development of the plastic zone on the fatigue crack tip, thus reducing mechanisms that could act to raise the value of the fatigue crack growth threshold and the fatigue resistance. This result has also been found in several other studies $22,54,55$.

\section{Conclusions}

A seamless steel pipe with apropriate chemical composition was considered in three distinct conditions as rolled, normalized and quenched and tempered. These conditions led to the achievement of three API $5 \mathrm{~L}$ grades, showing that the effective choice of heat treatments can give to the seamless steel pipe a set of characteristics that meet the API Standard, even considering a relatively simple chemical composition and conventional heat treatments. The microstructural modifications and mechanical properties changes observed showed the sensitivity of the steel to the structure-properties relationship, and attempt to a proper 


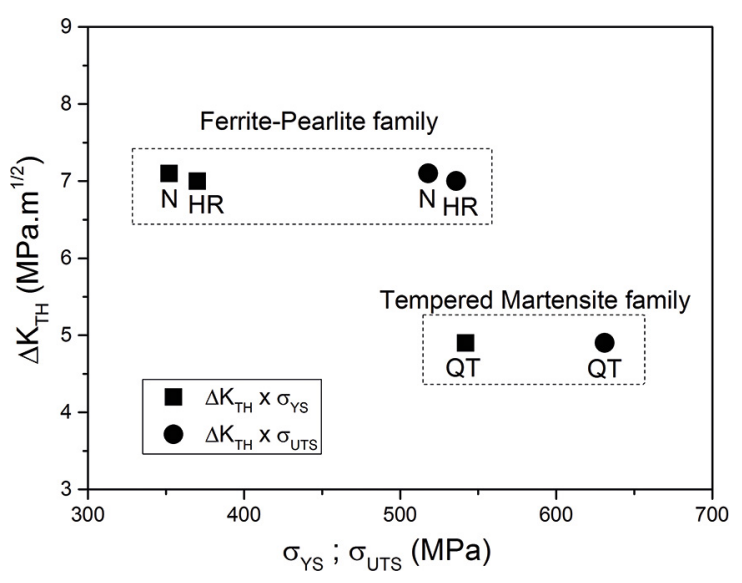

Figure 8. Fatigue threshold and tensile mechanical resistance relationship. $\mathrm{HR}=$ hot-rolled; $\mathrm{N}=$ normalized; $\mathrm{QT}=$ quenched and tempered.

selection as required by the structural design. The main conclusions are listed below.

1. The as-hot-rolled pipe presented a microstructure consisting of ferrite and pearlite, with basic mechanical properties that classified it as $\mathrm{X} 42 \mathrm{R}$.

2. The as-normalized pipe after hot rolling presented a microstructure also consisting of ferrite and pearlite, with basic mechanical properties that classified it as $\mathrm{X} 42 \mathrm{~N}$. Their mechanical strength and hardness were slightly lower than the X42R steel; its ductility and impact resistance were slightly higher than the X42R steel.

3. The quenched and tempered pipe after hot rolling presented a microstructure consisting of tempered martensite, bainite and precipitates, with basic mechanical properties that classified it as X70Q. Their basic mechanical properties were significantly higher than those steels of ferrite and pearlite microstructure.

4. The fracture toughness of $\mathrm{X} 70 \mathrm{Q}$ steel was higher than the X42R and X42N steels. Their fatigue resistance was lower, especially in the threshold region of crack growth.

\section{Acknowledgements}

VSB Company for providing the materials studied and CAPES for scholarship to Betânia Mendes Sena.

\section{References}

1. Li L, Xu L. Designing with High-Strength Low-Alloy Steels. In: Totten GE, Xie L, Funati K, eds. Handbook of Mechanical Alloy Design. New York: Marcel Dekker; 2004. p. 249-320.

2. Hillenbrand HG, Gräf M, Kalwa C. Development and production of high strength pipeline steels. In: Niobium Science \& Technology. Pittsburgh: TMS; 2001. p. 543-569.
3. Gray JM. An Independent View of Linepipe and Linepipe Steel for High Strength Pipelines: How to get Pipe that's Right for the Job at the Right Price. In: Proceedings of API-X80 Pipeline Cost Workshop; 2002 Oct 30; Hobart, Australia. Houston: ITI; 2002.

4. Hillenbrand HG, Kalwa C. Production and Service Behavior of High Strength Large Diameter Pipe. In: Proceedings of International Conference on Application and Evaluation of High Grade Linepipes in Hostile Environments; 2002 Nov 8-9; Yokohama, Japan. Ratingen: EUROPIPE; 2002.

5. Hillenbrand HG, Kalwa C. High strength line pipe for project cost reduction. World Pipelines. 2002;2(1):1-10.

6. Kalwa C, Hillenbrand HG, Gräf M. High strength steel pipes - new developments and applications. In: Proceedings of Onshore Pipeline Conference; 2002 Jun 10-11; Dallas TX, USA. Ratingen: EUROPIPE; 2002.

7. Gräf M, Hillenbrand HG, Heckmann CJ, Niederhoff KA. Highstrength large-diameter pipe for long-distance high-pressure gas pipelines. In: Proceedings of $13^{\text {th }}$ International Offshore and Polar Engineering Conference - ISOPE; 2003 May 26-30; Honululu, HI, USA. Ratingen: EUROPIPE; 2003.

8. Taiss EJM. O Mercado de Aços de Elevado Valor Agregado - Tendências Tecnológicas e a estratégia da Usiminas no Atendimento às Demandas. In: Workshop: Inovações para Desenvolvimento de Aços de Alto Valor Agregado - Tubos de Alta Resistência para Aplicações Estruturais e Transmissão de Fluídos. $62^{\circ}$ Congresso Anual da Associação Brasileira de Metalurgia e Materiais; 2007 Jul 23-27; Vitória, ES, Brazil. Associação Brasileira de Metalurgia e Materiais; 2007. CDROM (In Portuguese).

9. Siciliano F, Stalheim DG, Gray JM. Modern High Strength Steels for Oil and Gas Transmission Pipelines. In: Proceedings of $7^{\text {th }}$ International Pipeline Conference; 2008 Sep 29-Oct 3; Calgary, AB, Canada. Pittsburgh: TMS; 2008.

10. Gray JM, Siciliano F. High Strength Microalloyed Linepipe: Half a Century of Evolution. Houston: Microalloyed Steel Institute; 2009. p. 20-45.

11. Barbaro F, Fletcher L, Dinnis C, Piper J, Gray JM. Design and specification of line pipe and line pipe steels for weldability, constructability and integrity. In: Proceedings of APIA / EPRG / PRCI $18^{\text {th }}$ JTM on Pipeline Research; 2011 May 16-20; San Francisco, CA, USA.

12. American Petroleum Institute. Specification for Line Pipe. ANSI/API Specification $5 \mathrm{~L}, 4^{\text {th }}$ Ed. Washington: American Petroleum Institute; 2012.

13. Maiti R, Nadeau JS, Hawbolt EB. The characterization of fracture toughness of two X-70 pipeline steels. Journal of Materials for Energy Systems. 1980;2(1):34-50.

14. Shin SY, Hwang B, Kim S, Lee S. Fracture toughness analysis in transition temperature region of API X70 pipeline steels. Materials Science and Engineering: A. 2006;429(1-2):196-204.

15. Shin YT, Kang SW, Lee HW. Fracture characteristics of TMCP and QT steel weldments with respect to crack length. Materials Science and Engineering: A. 2006;434(1-2):365-371.

16. Ju JB, Lee JS, Jang JI. Fracture toughness in a API steel linepipe. Materials Letters. 2007;61(29):5178-5180. 
17. Toffolo RB, Cândido LC, Godefroid LB, Mattioli R. Fracture behavior of two API steels used in iron ore pipelines. In: Proceedings of IX Brazilian MRS Meeting; 2010 Oct 24-28, Ouro Preto, MG, Brazil.

18. El-Danaf E, Baig M, Almajid A, Alshalfan W, Al-Mojil M, AlShahrani S. Mechanical, microstructure and texture characterization of API X65 steel. Materials \& Design. 2013;47:529-538.

19. Shin SY, Woo KJ, Hwang B, Kim S, Lee S. Fracture-Toughness Analysis in Transition-Temperature Region of Three American Petroleum Institute X70 and X80 Pipeline Steels. Metallurgical and Materials Transactions A. 2009;40(4):867-876.

20. Zhong Y, Xiao F, Zhang J, Shan Y, Wang W, Yang K. In situ TEM study of the effect of M/A films at grain boundaries on crack propagation in an ultra-fine acicular ferrite pipeline steel. Acta Materialia. 2006;54(2):435-443.

21. Kim Y, Kim C, Kim W, Song K, Shin K. Near-threshold Fatigue Crack Growth Behavior and Crack Closure of Natural Gas Pipeline Steels. Procedia Engineering. 2011;10:813-820.

22. Godefroid LB, Cândido LC, Toffolo RB, Barbosa LH. Microstructure and mechanical properties of two API steels for iron ore pipelines. Materials Research. 2014;17(Suppl 1):114-120.

23. Iwasaki Y, Kobayashi K, Ueno K, Koyama Y. Production of HSLA Seamless Steel Pipes for Offshore Structures and Line Pipes by Direct-Quench and Tempering. Transactions of the Iron and Steel Institute of Japan. 1985;25(10):1059-1068.

24. Bai D, Collins F, Hamad F, Chen X, Klein R. Microstructure and Mechanical Properties of High Strength Linepipe Steels. MS\&T 2007: Proceedings from the Materials Science \& Technology Conference; 2007 Sep 16-20; Detroit, MI, USA. p. 355-366.

25. Shin SY, Hwang B, Lee S, Kim NJ, Ahn SS. Correlation of microstructure and charpy impact properties in API X70 and X80 line-pipe steels. Materials Science and Engineering: $A$. 2007;458(1-2):281-289.

26. Shanmugam S, Ramisetti NK, Misra RDK, Hartmann J, Jansto SG. Microstructure and high strength-toughness combination of a new $700 \mathrm{MPa} \mathrm{Nb}$-microalloyed pipeline steel. Materials Science and Engineering: A. 2008;478(1-2):26-37.

27. Sun L, Zhang C, Wang Q, Wang M, Yan Z. Prediction of mechanical properties of $25 \mathrm{CrMo} 48 \mathrm{~V}$ seamless tube using neural network model. International Journal of Modern Physics B. 2009;23(6-7):1074-1079.

28. Han SY, Shin SY, Seo CH, Lee H, Bae JH, Kim K, et al. Effects of $\mathrm{Mo}, \mathrm{Cr}$ and $\mathrm{V}$ Additions on Tensile and Charpy Impact Properties of API X80 Pipeline Steels. Metallurgical and Materials Transactions A. 2009;40:1851-1862.

29. Liu SX, Chen Y, Liu GQ, Zhang YG, Huang JK. Effect of intermediate cooling on precipitation behavior and austenite decomposition of V-Ti-N steel for non-quenched and tempered oil-well tubes. Materials Science and Engineering: $A$. 2008;485(1-2):492-499.

30. Zhang CY, Wang QF, Kong JL, Xie GZ, Wang MZ, Zhang FC. Effect of Martensite Morphology on Impact Toughness of UltraHigh Strength 25CrMo48v Steel Seamless Tube Quenched at Different Temperatures. Journal of Iron and Steel Research, International. 2013;20(2):62-67.
31. Sami Z, Tahar S, Mohamed H. Microstructure and Charpy impact properties of ferrite-martensite dual phase API X70 linepipe steel. Materials Science and Engineering: A. 2014;598:338-342.

32. Souza FHS. Avaliação da tenacidade à fratura pela técnica de CTOD para o tubo de aço X65Q API $5 L$ hidrogenado em ambiente com H2S. [Dissertação]. Belo Horizonte: Pontifícia Universidade Católica de Minas Gerais; 2011. 132 f.

33. Araujo LCS. Avaliação da influência de tratamentos térmicos pós-soldagem na microestrutura e propriedades mecânicas de juntas de um aço API 5L. [Dissertação]. Ouro Preto: Universidade Federal de Ouro Preto; 2013. 86 f.

34. Trindade Filho VB. Relação microestrutura e propriedades mecânicas de aços/graus API 5L e API 5CT. In: $68^{\circ}$ Congresso Anual da Associação Brasileira de Metalurgia, Materiais e Mineração (ABM); 2013 Jul 30-Aug 2; Belo Horizonte, MG, Brasil.

35. American Society for Testing and Materials. ASTM E112: Standard Test Methods for Determining Average Grain Size. West Conshohocken: ASTM International; 2012.

36. American Society for Testing and Materials. ASTM E1268: Standard Practice for Assessing the Degree of Banding or Orientation of Microstructures. West Conshohocken: ASTM International; 2007.

37. American Society for Testing and Materials. ASTM E1820: Standard Test Method for Measurement of Fracture Toughness. West Conshohocken: ASTM International; 2015.

38. American Society for Testing and Materials. ASTM E647: Standard Test Method for Measurement of Fatigue Crack Growth Rates. West Conshohocken: ASTM International; 2015.

39. Gray JM, Pontremoli M. Metallurgical options for API 5L grades X65, X70 and X80 linepipe. International Conference Pipe Technology; 1987 Nov 17-19; Rome, Italy.

40. Dhua SK, Mukerjee D, Sarma DS. Weldability and Microstructural Aspects of Shielded Metal Arc Welded HSLA-100 Steel Plates. ISIJ International. 2007;42(3):290-298.

41. Thompson SW, Howell PR. Factors influencing ferrite/pearlite banding and origin of large pearlite nodules in a hypoeutectoid plate steel. Materials Science and Technology. 1992;8(9):777-784.

42. Krauss G. Solidification, segregation, and banding in carbon and alloy steels. Metallurgical and Materials Transactions B. 2003;34(6):781-792.

43. Taira T, Yamaguchi T, Iwasaki N, Tsukada K, Koshiga F. Development of heavy wall X65 line pipes manufactured from quenched and tempered plates for low temperature service. In: Proceedings of the $18^{\text {th }}$ Mechanical Working \& Steel Processing Conference; 1976 Jan 21-22; Chicago, IL, USA.

44. Shehata MT, Boyd JD. Quantitative correlations between toughness and microstructure for commercial line pipe steel. In: Proceedings of Conference on Advances in the Physical Metallurgy and Applications of Steels; 1981 Sep 21-24; Liverpool, United Kingdom. London: Metals Society; 1982. p. 229-236.

45. Zhao MC, Yang K, Shan YY. The effects of thermo-mechanical control process on microstructures and mechanical properties of a commercial pipeline steel. Materials Science and Engineering: A. 2002;335(1-2):14-20. 
46. Zhao MC, Yang K, Shan YY. Comparison on strength and toughness behaviors of microalloyed pipeline steels with acicular ferrite and ultrafine ferrite. Materials Letters. 2003;57(9-10):1496-1500.

47. Xiao F, Liao B, Ren D, Shan YY, Yang K. Acicular ferritic microstructure of a low-carbon $\mathrm{Mn}-\mathrm{Mo}-\mathrm{Nb}$ microalloyed pipeline steel. Materials Characterization. 2005;54(45):305-314.

48. Stalheim DG, Barnes K, McCutcheon DB. Alloy Designs for High Strength Oil and Gas Transmission Linepipe Steels. In: International Symposium Microalloyed Steels for the Oil and Gas Industry. 2006 Jan 23-26; Araxá, MG, Brazil. CBMM/ TMS; 2006. CD-ROM.

49. Xiao FR, Liao B, Shan YY, Qiao GY, Zhong Y, Zhang C, et al. Challenge of mechanical properties of an acicular ferrite pipeline steel. Materials Science and Engineering: A 2006;431(1-2):41-52.

50. Shanmungam S, Misra RDK, Hartmann J, Jansto SG. Microstructure of high strength niobium-containing pipeline steel. Materials Science and Engineering: A. 2006;441(1-2):215-229.
51. Wang W, Shan YY, Yang K. Study of high strength pipeline steels with different microstructures. Materials Science and Engineering: A. 2009;502(1-2):38-44.

52. Wang W, Yan W, Zhu L, Hu P, Shan YY, Yang K. Relation among rolling parameters, microstructures and mechanical properties in an acicular ferrite pipeline steel. Materials \& Design. 2009;30(9):3436-3443.

53. Smirnov MA, Pyshmintsev IY, Maltseva AN, Mushina OV. Effect of ferrite-bainite structure on the properties of high-strength pipe steel. Metallurgist. 2012;56(1):43-51.

54. Rodrigues EM, Matias A, Godefroid LB, Bastian FL, Al-Rubaie KS. Fatigue crack growth resistance and crack closure behavior in two aluminum alloys for aeronautical applications. Materials Research. 2005;8(3):287-291.

55. Godefroid LB, Andrade MS, Machado FA, Horta WS. Effect of prestrain and bake hardening heat treatment on fracture toughness and fatigue crack growth resistance of two dual-phase steels. In: Proceedings of Materials Science and Technology 2011 Conference (MS\&T 2011); 2011 Oct 16-20; Columbus, OH, USA. 